\title{
Positive Education to Promote Flourishing in Students Returning to School after COVID-19 Closure
}

\author{
Gökmen Arslan ${ }^{1}$ (i) and Jolanta Burke ${ }^{2}$ (iD
}

As the Coronavirus (COVID-19) global disaster continues to unfold across the world, protective measures such as school closures, physical distancing, and stay-at-home orders have exposed wide numbers of young people to fear, worry, distress, academic challenges (e.g., amotivation), loneliness, depression, anxiety and they were particularly detrimental to children with special needs (Arslan, 2021; Arslan \& Y1ldırım, 2021; Bobo et al., 2020; O'Sullivan et al., 2021; Patrick et al., 2020; Quinn et al., 2021), Undoubtedly, one of the biggest disruptions for young people and the whole school community has been the rapid shift to remote learning (Castro \& George, 2021; Flynn et al., 2021; Kim \& Asbury, 2020).

Peer-reviewed research on the impact of school closures and remote learning triggered by the COVID-19 pandemic is only just emerging, but the few studies that are available have produced mixed results (Asanov et al., 2020; Watera et al., 2021). Some students have benefited from learning at home, making the most of being able to learn at their own pace and appreciating the calm of home compared to a noisy classroom (Lee, 2020). For others, the pandemic heralded change in their own preferences, whereby they were more likely to opt for online classes when given a choice (Castro \& George, 2021). However, the majority of students have experienced negative effects, including high academic distress (Horita et al., 2021), decreased learning effectiveness (Di Pietro et al., 2020; Owusu-Fordjour et al., 2020), reduced motivation to learn (Garbe et al., 2020), lack of personal space at home (Wang et al., 2020) and struggling to balance school and home responsibilities (Garbe et al., 2020). The negative effect of school closures is amplified for students who live in marginalized communities and areas where they were already exposed to intersecting vulnerabilities (e.g., war, displacement, poverty, and weak healthcare and education systems; Banati et al., 2020).

In addition, educators and school-based mental health providers across the world are wondering how school or education will look when students return to school settings. Most importantly, they are wondering how to promote staff and students' mental health and flourishing, regardless of the setting (Arslan et al., 2021; Asby et al., 2020). Specifically, positive education approaches can be an important resource to promote resilience and flourishing in students returning to school after COVID-19 school closure.

Positive education, a positive psychology-based approach, emphasizes the need to support student character and wellbeing skills in school context (Seligman et al., 2009). In addition to the traditional academic approaches, positive education aims to develop and foster young people's strengths and skills for happiness and psychological, social and emotional health in educational context (Morgan \& Simmons, 2021). Previous research indicated the effectiveness of positive psychology-based approaches (e.g., positive education) on positive youth development and wellbeing

Positive education calls for tweaking the curriculum to incorporate teaching content that enhances wellbeing. For example, helping young people reflect on life goals, promote aspirations conducive to wellbeing (Gill et al., 2021), practice positive psychology interventions (PPIs) such as three good things, signature strengths or writing a gratitude letter (Bridges et al., 2012), engaging with a positive education programmes, such as Strengths Gym, Penn Resiliency, or Making Hope Happen (Lopez, 2013; Proctor et al., 2011; Reivich \& Gillham, 2010), or creating

${ }^{1}$ Department of Psychological Counseling and Guidance, Burdur Mehmet Akif Ersoy University, Burdur, Turkey. Contact: garslan@mehmetakif.edu.tr

${ }^{2}$ Centre for Positive Psychology and Health, RCSI University of Medicine and Health Sciences, Ireland.

Contact: jolantaburke@rcsi.ie 
school-customised activities informed by positive psychology research, such as PROSPER, PERMAH, or FLOURISH frameworks (Noble \& McGrath, 2015; Williams, 2011). However, positive education extends beyond teaching young people wellbeing skills and practicing PPIs, as it encourages the application of positive pedagogy to boost school community's wellbeing (Burke, 2021).

Positive pedagogy relates to incorporating pedagogical approaches in teachers' daily practice that make positive impact on students' and teachers' wellbeing. This includes pedagogies encouraging students' creativity that stretch beyond the arts subject and towards maths, language, science, technology, social sciences, physical education classes (Patston et al., 2021), shortening teacher long-winded instructions (Goemaere et al., 2018), or structured group play (Woolf, 2011). Alternatively, it incorporates a range of pedagogies that relate to positive learning experiences (e.g. being flexible, offering awards), teacher-child relationship improvement (e.g. appreciating children), or supporting children's autonomy (Ranta et al., 2020). Considering the impact of teachers on students (Harding et al., 2019), tweaks in teachers' pedagogies can have a positive ripple effect across the entire school community.

In the world obliterated by the negative COVID-19 experiences, positive education has an important role to play. It can help students and teachers tap into their strengths (Galloway et al., 2020), enable them to use and regulate their psychological, social and emotional resources to their full potential (Freire \& Tavares, 2016; Morrish et al.,, 2018), and boost their wellbeing (Au \& Kennedy, 2018; Waters, 2017), not only by implementing additional activities, but also by doing more of what is already working as well as tweaking the current practices to achieve better results. When applied with care, and cognisant of ecological and cultural factors affecting each school community (Coulombe et al., 2021; Lombardi et al., 2019), it has a potential of changing the lives of millions of children, teachers and parents worldwide.

\section{Conclusion}

Although we hope for this public crisis to end soon, the effects of pandemic on youth valued outcomes signify that there is need to design mental health services to cultivate wellbeing and mental health in young people returning to school after coronavirus school closure. Positive psychology literacy is thus necessary for developing science that informed evidence helping students to cope with the challenges and providing positive adaptation after returning to schools. In this regard, we encourage researchers, mental health providers, and school authorities to develop effective interventions in educational context to support students' flourishing and academic development. We believe that application of the principles of positive psychology that emphasizes student strengths and skills into school context can play a key role for the promotion of mental health and wellbeing. The Journal of School and Educational Psychology (JOSEP) thus engages these efforts and invites manuscripts informing educators and mental health providers of best positive psychology-based practices that sustain staff, parents, students' resilience and wellbeing during this most challenging worldwide emergency.

ORCID

Gökmen Arslan@https://orcid.org/0000-0001-9427-1554

Jolanta Burke@https://orcid.org/0000-0003-2209-782X

Published Online: August 25, 2021

\section{References}

Arslan, G. (2021). Loneliness, college belongingness, subjective vitality, and psychological well-being during coronavirus pandemic: Preliminary development of the College Belongingness Questionnaire. Journal of Positive School Psychology, 5(1), 17-31. https://doi.org/10.47602/jpsp.v5i1.240

Arslan, G. \& Yıldırım, M. (2021). Perceived risk, positive youth-parent relationships, and internalizing problems in adolescents: Initial development of the Meaningful School Questionnaire. Child Indicators Research. https://doi.org/10.1007/s12187-021-09841-0 
Arslan, G., Yildirim, M., \& Zangeneh, M. (2021). Coronavirus anxiety and psychological adjustment in college students: Exploring the role of college belongingness and social media addiction. International Journal of Mental Health and Addiction. https://doi.org/10.1007/s11469-020-00460-4

Asanov, I., Flores, F., McKenzie, D., Mensmann, M., \& Schulte, M. (2020). Remote-learning, time-use, and mental health of Ecuadorian high-school students during the COVID-19 quarantine. World Development, 138, 105225. https://doi.org/10.1016\%2Fj.worlddev.2020.105225

Au, W. C. C., \& Kennedy, K. J. (2018). A positive education program to promote wellbeing in schools: A case study from a Hong Kong school. Higher Education Studies, 8(4), 9-22.

Banati, P., Jones, N., \& Youssef, S. (2020). Intersecting vulnerabilities: The impacts of COVID-19 on the psychoemotional lives of young people in low- and middle-income countries. The European Journal of Development Research, 1-26. https://doi.org/10.1057/s41287-020-00325-5

Bobo, E., Lin, L., Acquaviva, E., Caci, H., Franc, N., Gamon, L., Picot, M.-C., Pupier, F., Speranza, M., Falissard, B., \& Purper-Ouakil, D. (2020). How do children and adolescents with Attention Deficit Hyperactivity Disorder (ADHD) experience lockdown during the COVID-19 outbreak? L'Encéphale: Revue de Psychiatrie Clinique Biologique et Thérapeutique, 46(3), S85-S92. https://doi-org.jproxy.nuim.ie/10.1016/j.encep. 2020.05.011

Bridges, K. R., Harnish, R. J., \& Sillman, D. (2012). Teaching undergraduate positive psychology: An active learning approach using student blogs. Psychology Learning and Teaching, 11(2), 218-227. doi: 10.2304/plat.2012.11.2.228

Burke, J. (2021). The ultimate guide to implementing wellbeing programmes for school. London/New York: Routledge.

Castro, E., \& George, J. (2021). The impact of COVID-19 on student perceptions of education and engagement. EJournal of Business Education \& Scholarship of Teaching, 15(1), 29-39.

Coulombe, S., Hardy, K., \& Goldfarb, R. (2020). Promoting wellbeing through positive education: A critical review and proposed social ecological approach. Theory and Research in Education, 18(3), 295-321.

Di Pietro, G., Biagi, F., Costa, P., Karpiński Z., \& Mazza, J. (2020). The likely impact of COVID-19 on education: Reflections based on the existing literature and international datasets (EUR 30275 EN). Publications Office of the European Union. https://doi.org/10.2760/126686

Flynn, N., Keane, E., Davitt, E., McCauley, V., Heinz, M., \& Mac Ruairc, G. (2021). "Schooling at Home" in Ireland during COVID-19': Parents' and students' perspectives on overall impact, continuity of interest, and impact on learning. Irish Educational Studies, 40(2), 217-226. https://doiorg.jproxy.nuim.ie/10.1080/03323315.2021.1916558

Freire, T., \& Tavares, D. (2016). Affect, emotion regulation and flow experience in school and leisure: Contributions for a positive education. In B. Zufiaurre \& M. P. de Villarreal (Eds.), Positive psychology for positive pedagogical actions. (pp. 61-74). Nova Science Publishers.

Galloway, R., Reynolds, B., \& Williamson, J. (2020). Strengths-Based teaching and learning approaches for children: perceptions and practices. Journal of Pedagogical Research, 4(1), 31-45.

Garbe, A., Ogurlu, U., Logan, N., \& Cook, P. (2020). COVID-19 and remote learning: Experiences of parents with children during the pandemic. American Journal of Qualitative Research, 4(3), 45-65. https://doi.org/10.29333/ajqr/8471

Goemaere, S, Beyers, W., de Muynck,G-J, \& Vvansteenkiste, M. (2018). The paradoxical effect of long instructions on negative affect and performance: When, for whom and why they backfire? Acta Astronautica, 147, 421430.

Gill, A., Trask-Kerr, K., \& Vella-Brodrick, D. (2021). Systematic review of adolescent conceptions of success: Implications for wellbeing and positive education. Educational Psychology Review. https://doiorg.jproxy.nuim.ie/10.1007/s10648-021-09605-w

Harding, S., Morris, R., Gunnell, D., Ford, T., Hollingworth, W., Tilling, K., Evans, R., Bell, S., Grey, J., Brockman, R., Campbell, R., Araya, R., Murphy, S., \& Kidger, J. (2019). Is teachers' mental health and wellbeing associated with students' mental health and wellbeing? Journal of Affective Disorders, 253, 460-466. https://doi-org.jproxy.nuim.ie/10.1016/j.jad.2019.03.046 
Horita, R., Nishio, A., \& Yamamoto, M. (2021). The effect of remote learning on the mental health of first year university students in Japan. Psychiatry research, 295, 113561. https://doi.org/10.1016/j.psychres. 2020.113561

Kim, L. E., \& Asbury, K. (2020). "Like a rug had been pulled from under you": The impact of COVID-19 on teachers in England during the first six weeks of the UK lockdown. British Journal of Educational Psychology, 90(4), 1062-1083. https://doi-org.jproxy.nuim.ie/10.1111/bjep.12381

Lee, J. (2020). Mental health effects of school closures during COVID-19. The Lancet Child \& Adolescent Health, 4(6), 421. https://doi.org/10.1016/S2352-4642(20)30109-7

Lombardi, E., Traficante, D., Bettoni, R., Offredi, I., Giorgetti, M., \& Vernice, M. (2019). The impact of school climate on well-being experience and school engagement: A study with high-school students. Frontiers in Psychology, 10. https://doi-org.jproxy.nuim.ie/10.3389/fpsyg.2019.02482

Lopez, S. J. (2013). Making hope happen in the classroom. Phi Delta Kappan, 95(2), 19-22. https://doi.org/10.1177/003172171309500205

Morgan B and Simmons L (2021) A 'PERMA' response to the pandemic: An online positive education programme to promote wellbeing in university students. Frontiers in Education, 6, 642632. https://doi.org/10.3389/feduc.2021.642632

Morrish, L., Rickard, N., Chin, T. C., \& Vella-Brodrick, D. A. (2018). Emotion regulation in adolescent well-being and positive education. Journal of Happiness Studies, 19(5), 1543-1564. https://doiorg.jproxy.nuim.ie/10.1007/s10902-017-9881-y

Noble, T., \& McGrath, H. (2015). PROSPER: A new framework for positive education. Psychology of Wellbeing, 5(1), 1-17.

O'Sullivan, K., Clark, S., McGrane, A., Rock, N., Burke, L., Boyle, N., Joksimovic, N., \& Marshall, K. (2021). A Qualitative Study of Child and Adolescent Mental Health during the COVID-19 Pandemic in Ireland. International Journal of Environmental Research and Public Health, 18(3), 1062. https://doi.org/10.3390/ijerph18031062.

Patrick, S. W., Henkhaus, L. E., Zickafoose, J. S., Lovell, K., Halvorson, A., Loch, S., Letterie, M., \& Davis, M. M. (2020). Well-being of parents and children during the COVID-19 pandemic: A national survey. Pediatrics, 146(4). https://doi-org.jproxy.nuim.ie/10.1542/peds.2020-016824

Patston, T. J., Kaufman, J. C., Cropley, A. J., \& Marrone, R. (2021). What Is Creativity in Education? A Qualitative Study of International Curricula. Journal of Advanced Academics, 32(2), 207-230. https://doiorg.jproxy.nuim.ie/10.1177/1932202X20978356

Proctor, C., Tsukayama, E., Wood, A. M., Maltby, J., Eades, J. F., \& Linley, P. A. (2011). Strengths gym: The impact of a character strengths-based intervention on the life satisfaction and well-being of adolescents. Journal of Positive Psychology, 6(5), 377-388.

Quinn, P., McGilloway, S., \& Burke, J. (2021). COVID-19 and the class of 2020: a national study of the mental health and wellbeing of Leaving Certificate students in Ireland. Irish Educational Studies, 40(2), 375-384. https://doi-org.jproxy.nuim.ie/10.1080/03323315.2021.1916564

Ranta, S., Uusiautti, S., \& Hyvärinen, S. (2020). The implementation of positive pedagogy in Finnish early childhood education and care: A quantitative survey of its practical elements. Early Child Development and Care. https://doi.org/10.1080/03004430.2020.1763979

Reivich, K., \& Gillham, J. (2010). Building Resilience in Youth: The Penn Resiliency Program. Communique, $38(6), 1-17$.

Schiavon, C. C., Teixeira, L. P., Gurgel, L. G., Magalhães, C. R., \& Reppold, C. T. (2020). Positive education: Innovation in educational interventions based on positive psychology. Psicologia: Teoria e Pesquisa, 36. https://doi-org.jproxy.nuim.ie/10.1590/0102.3772e3632

Seligman, M., Ernst, R., Gillham, J., Reivich, K., \& Linkin, M. (2009). Positive education: Positive psychology and classroom interventions. Oxford Review of Education, 35(3), 293-311. https://doi.org/10.1080/03054980902934563 
Wang, G., Zhang, Y., Zhao, J., Zhang, J., \& Jiang, F. (2020). Mitigate the effects of home confinement on children during the COVID-19 outbreak. The Lancet, 395(10228), 945-947. https://doi.org/10.1016/S01406736(20)30547-X

Waters L, Allen K-A, \& Arslan G (2021) Stress-related growth in adolescents returning to school after COVID-19 school closure. Frontiers in Psychology, 12, 643443. https://doi.org/10.3389/fpsyg.2021.643443

Waters, L., Sun, J., Rusk, R., Cotton, A., \& Arch, A. (2017). Positive education: Visible wellbeing and positive functioning in students. In M. Slade, L. Oades, \& A. Jarden (Eds.), Wellbeing, recovery and mental health. (pp. 245-264). Cambridge University Press. https://doi-org.jproxy.nuim.ie/10.1017/9781316339275.021

Williams, P. (2011). Pathways to positive education at Geelong Grammar School. Integrating positive psychology and appreciative inquiry. AI Practitioner, 13(2), 8-13

Woolf, A. (2011). Everyone Playing in Class: a group play provision for enhancing the emotional well-being of children in school. British Journal of Special Education, 38(4), 178-190. https://doiorg.jproxy.nuim.ie/10.1111/j.1467-8578.2011.00520.x 